\title{
Seckel Syndrome: case report of functional motor recovery using proprioceptive neuromuscular facilitation/Kabat Method
}

Síndrome de Seckel: relato de caso de recuperação motora funcional utilizando facilitação neuromuscular proprioceptiva / Método de Kabat

Síndrome de Seckel: reporte de caso de recuperación motora funcional mediante facilitación neuromuscular propioceptiva / Método Kabat

Jeferson de Lima Souza

ORCID: https://orcid.org/0000-0002-0543-0515 Universidade Federal de Sergipe, Brazil E-mail: dr.jefersonsouzza@gmail.com Miburge Bolivar Gois Júnior ORCID: https://orcid.org/0000-0003-1149-8126 Universidade Federal de Sergipe, Brazil E-mail: miburgejr@hotmail.com

Diogo Costa Garção

ORCID: https://orcid.org/0000-0001-9456-6563 Universidade Federal de Sergipe, Brazil

E-mail: diogoufscar@yahoo.com.br

Elenilton Correia de Souza

ORCID: https://orcid.org/0000-0002-0735-5918 Universidade Federal de Sergipe, Brazil

E-mail: elenilton2010@gmail.com

Isaac Rafael Silva Lima

ORCID: https://orcid.org/0000-0002-4820-1042 Universidade Federal de Sergipe, Brazil E-mail: isaacrafael_fisio@hotmail.com

Olga Sueli Marques Moreira

ORCID: https://orcid.org/0000-0002-0415-036X Universidade Federal de Sergipe, Brazil E-mail: marquesosm@yahoo.com.br

\begin{abstract}
Introduction: Seckel syndrome (SCKL) is a heterogeneous autosomal recessive disorder, the major characteristic of which is microcephalic osteodysplastic dwarfism, which is defined as severe intrauterine growth retardation, severe short stature, severe microcephaly, bird-like profile, retroverted chin and forehead, prominent nose, mental retardation and other congenital anomalies. Objective: Evaluate the therapeutic effect of proprioceptive neuromuscular facilitation/Kabat method (PNF/KM) for functional recovery in SCKL. Methods: A pre-treatment evaluation was performed, followed by an intervention involving PNF/KM. Sessions were held twice a week for ten weeks (total: 20 sessions), followed by a post-treatment evaluation. The evaluator and the therapist were blinded. The assessment instruments were Lawton \& Brody's Activities of Daily Living (ADL) Scale, Disabilities of Arm, Shoulder and Hand (DASH), Short Physical Performance Battery, Timed Up and Go test and upper limb muscle strength using a digital dynamometer. Results: No significant changes were found regarding ADL Scale or DASH. However, functional gains were achieved in activities that require biomechanical and proprioceptive actions of the shoulder, arm and wrist. Regarding the Short Physical Performance Battery, improvement was found in variables that require stabilization, strength, balance and agility. An improvement was found in the execution speed of the Timed Up and Go test. An improvement in muscle strength was following the intervention. Conclusion: This study showed that the PNF/KM method was not able to improve the performance on activities of daily living, but improvements were found with regards to balance, stabilization, strength and agility of the upper limbs and lower limbs.
\end{abstract}

Keywords: Seckel syndrome; Rehabilitation; Propioceptive neuromuscular facilitation; Kabat method.

\section{Resumo}

Introdução: A síndrome de Seckel (SCKL) é um distúrbio autossômico recessivo heterogêneo, cuja principal característica é o nanismo osteodisplásico microcefálico, que é definido como retardo de crescimento intrauterino grave, baixa estatura severa, microcefalia severa, perfil de ave, queixo e testa retrovertidos, nariz proeminente, retardo 
mental e outras anomalias congênitas. Objetivo: Avaliar o efeito terapêutico da facilitação neuromuscular proprioceptiva / método Kabat (PNF / KM) para recuperação funcional em SCKL. Métodos: Foi realizada avaliação pré-tratamento, seguida de intervenção envolvendo PNF / KM. As sessões foram realizadas duas vezes por semana durante dez semanas (total: 20 sessões), seguidas de uma avaliação pós-tratamento. O avaliador e a terapeuta estavam cegos, metodologicamente. Os instrumentos de avaliação foram Lawton \& Brody ' s Escala de Atividades de Vida Diária (AVD), Deficiências de Braço, Ombro e Mão (DASH), Bateria de Desempenho Físico Curto, Teste Timed Up and Go e força muscular de membro superior usando um dinamômetro digital. Resultados: Não foram encontradas mudanças significativas em relação à escala de AVD ou DASH. No entanto, ganhos funcionais foram alcançados em atividades que requerem ações biomecânicas e proprioceptivas do ombro, braço e punho. Em relação à Bateria Curta de Desempenho Físico, houve melhora nas variáveis que requerem estabilização, força, equilíbrio e agilidade. Uma melhoria foi encontrada na velocidade de execução do teste Timed Up and Go. Uma melhora na força muscular estava seguindo a intervenção. Conclusão: Este estudo mostrou que o método PNF / KM não foi capaz de melhorar o desempenho nas atividades de vida diária, mas foram encontradas melhorias no que diz respeito ao equilíbrio, estabilização, força e agilidade de membros superiores e inferiores.

Palavras-chave: Seckel syndrome; Reabilitação; Facilitação neuromuscular propioceptiva; Método de Kabat.

\section{Resumen}

Introducción: El síndrome de Seckel (SCKL) es un trastorno autosómico recesivo heterogéneo, cuya principal característica es el enanismo osteodisplásico microcefálico, que se define como retraso severo del crecimiento intrauterino, baja estatura severa, microcefalia severa, perfil de pájaro, mentón y frente retrovertidos, prominentes nariz, retraso mental y otras anomalías congénitas. Objetivo: Evaluar el efecto terapéutico de la facilitación neuromuscular propioceptiva / método de Kabat (PNF / KM) para la recuperación funcional en SCKL. Métodos: Se realizó una evaluación previa al tratamiento, seguida de una intervención con PNF / KM. Las sesiones se llevaron a cabo dos veces por semana durante diez semanas (total: 20 sesiones), seguidas de una evaluación posterior al tratamiento. El evaluador y el terapeuta estaban cegados. Los instrumentos de evaluación fueron Lawton \& Brody 's Escala de Actividades de la Vida Diaria (ADL), Discapacidades de Brazo, Hombro y Mano (DASH), Batería de Rendimiento Físico Corto, Prueba Timed Up and Go y fuerza de los músculos de las extremidades superiores usando un dinamómetro digital. Resultados: No se encontraron cambios significativos con respecto a la escala ADL o DASH. Sin embargo, se lograron ganancias funcionales en actividades que requieren acciones biomecánicas y propioceptivas del hombro, brazo y muñeca. En cuanto a la Batería de Rendimiento Físico Corto, se encontró mejora en variables que requieren estabilización, fuerza, equilibrio y agilidad. Se encontró una mejora en la velocidad de ejecución de la prueba Timed Up and Go. Después de la intervención, se produjo una mejora en la fuerza muscular. Conclusión: Este estudio mostró que el método PNF / KM no fue capaz de mejorar el desempeño en las actividades de la vida diaria, pero se encontraron mejoras en cuanto al equilibrio, la fuerza de estabilización y la agilidad de los miembros superiores e inferiores.

Palabras clave: Síndrome de Seckel; Rehabilitación; Facilitación neuromuscular propioceptiva; Método Kabat.

\section{Introduction}

Seckel syndrome (SCKL) is a heterogeneous autosomal recessive condition, the main clinical characteristic of which is microcephalic osteodysplastic dwarfism. According to data from Orphanet (2020), SCKL is a rare syndrome that was first described in 1959 by Mann and Russel. In 1960, Helmut Seckel described the main characteristics of the syndrome based on 13 cases in the literature and two cases studied personally. Seckel defined the syndrome as severe intrauterine growth retardation, severe short stature, severe microcephaly, bird-like profile, retroverted chin and forehead, prominent nose and mental retardation. Skeletal defects, abnormalities of the cardiovascular, hematopoietic, endocrine and central nervous systems, delayed bone age, Fanconi anemia, leukemia, chronic nephritis and defective development of the cerebral cortex and corpus callosum are also characteristics found in patients with SCKL (Seckel, 1960; Ceni, 2013; Sisodia et al., 2014; Orphanet, 2020).

According to Vascone et al. (2014), SCKL and primary autosomal recessive microcephaly, such as genetic microcephaly, are not distinct conditions. Both are characterized by microcephaly and the absence of visceral malformations, as stature is no longer considered a discriminating characteristic (Vascone et al., 2014).

Besides a broad phenotypic heterogeneity among affected individuals, genetic heterogeneity was also demonstrated in a clinical review study conducted by Verloes et al. (2013), in which eight loci were identified: SCKL1 - gene: ATR; SCKL2 - 
gene: RBBP8; SCKL3 - gene: unknown; SCKL4 - gene: CENPJ; SCKL5 - gene: CEP152; SCKL6 - gene: CEP63; SCKL7 gene: NIN; and SCKL8 - gene: ATRIP. In another study, Vascone et al. (2014), identified three loci through the mapping of the homozygosis: SCKL1 [3q22.1-q24, ataxia-telangiectasia and gene of the protein related to Rad3 (ATR)], SCKL2 (18p11.31-q11.2, unknown gene) and SCKL3 (14q23, unknown gene). SCKL3 seems to be the predominant locus for SCKL (Verloes et al., 2013; Vascone et al., 2014).

The incidence of this syndrome is around 100 cases catalogued in the world since 1960. According to data from Orphanet in 2021, SCKL is a rare disease with an estimated prevalence/incidence of 0.2 per 100,000 live births, with only 50 cases/family published throughout the world. Thus, prenatal diagnosis of SCKL is extremely rare, as knowledge on the syndrome is limited to postnatal evaluations (Pachajoa et al., 2010; Akkurt et al., 2019; Orphanet, 2020).

The delay in normal motor development is due to the small diameter of the brain and primitive patterns, causing a delay in the acquisition of the phases of motor development, functional postures and transfers. The diminished motor independence can lead to skeletal, muscular and postural deformities (Umphred, 2011).

Physiotherapeutic intervention is indicated as early as possible to stimulate normal motor development in children with conditions such as Down syndrome, cerebral palsy, Duchenne muscular dystrophy, etc. A number of methods are used for functional stimulation in such cases, such as the Bobath method, Cuevas Medek, hydrotherapy and Rolfing. The Kabat method $(\mathrm{KM})$ consists of proprioceptive neuromuscular facilitation (PNF) to enable the acquisition of motor functions based on the stimulation of proprioceptors to increase the demand imposed on the neuromuscular mechanism. The method was selected for the present study to investigate the response to an intervention with complex in diagonals and spirals related to the principle of the irradiation of forces and proprioceptive stimulation in the acquisition of sensory-motor function (Cruz-Machado et al., 2007; Ceni, 2013; Cilento et al., 2018).

As a rare syndrome, there are no scientific articles on treatment for SCKL using PNF/KM. Affected individuals exhibit hypotonia, low muscle strength and diminished range of motion (ROM), with negative impacts on gait and balance. Thus, there is a need for interventions with techniques that enhance proprioception, particularly muscle spindles, to facilitate muscle contraction and maximize postural reactions.

The present study involved the participation of a male patient with SCKL in the city of Moita Bonita (state of Sergipe, Brazil) to investigate the effects of PNF/KM with regards to improvements in activities of daily living, functional performance of the arm, shoulder and hand, lower limb performance, the risk of falls and upper limb muscle strength. Thus, the aim of this study was to investigate the effects of PNF/KM on functional recovery in SCKL. The relevance of this study resides in its pioneering nature for the subsequent development of future scientific research involving SCKL and interventions with neurofunctional physiotherapy.

\section{Methodology}

\section{Study design}

This is a case study, the methodology of which refers to a detailed analysis of an individual case that explains the dynamics and pathology of a particular disease. Through this procedure, it is assumed that it is possible to acquire knowledge of the phenomenon studied from the intense exploration of a single case. The design of this type of study represents an empirical investigation and comprises a comprehensive method, with the logic of organization, collection and analysis of data. Therefore, it can include both single and multiple case studies, as well as quantitative and qualitative research approaches (Ventura, 2007). A longitudinal case report study was conducted involving an 18-year-old male with a clinical diagnosis of SCKL after authorization granted by a legal guardian through the signing of a statement of informed consent. 
The evaluations were performed by a blinded examiner prior to the intervention and after the last session (postintervention). The therapist in charge of the intervention was also blinded. The evaluations involved the Lawton \& Brody Scale (1969) for the assessment of performance on activities of daily living, Disabilities of the Arm, Shoulder and Hand (DASH) scale for the investigation of dysfunction and limitations of the upper limbs, the Short Physical Performance Battery (SPPB) for the assessment of functional performance of the lower limbs; the Timed Up and Go (TUG) test for the assessment of the risk of falls and a digital dynamometer (Instrutherm ${ }^{\circledR}$, model DM-90) for the assessment of upperlimb muscle strength.

\section{Setting}

This study was developed at the Serapião de Gois Primary Care Unit located on Av. João Evangelista da Costa in the municipality of Moita Bonita, state of Sergipe, Brazil.

\section{Sample}

An 18-year-old male (weight: $34.8 \mathrm{~kg}$; height: $1.52 \mathrm{~m}$ ) diagnosed with SCKL 14 years earlier participated in the present study. The patient performed hydrotherapy twice per week and physiotherapy based on demand at the local primary care unit. The guardian reported that the patient had undergone physiotherapy since three years of age, which did not involve $\mathrm{PNF} / \mathrm{KM}$. Physiotherapeutic treatment was interrupted two months prior to the onset of the present study, which was justified by the need for the study.

\section{Procedures and evaluation instruments:}

$\mathrm{PNF} / \mathrm{KM}$ was administered by a physiotherapist trained in the technique and blinded to the procedure. Twenty sessions were held at a frequency of two sessions per week. The exercises were performed in three sets of ten repetitions with a one-minute rest interval between sets. PNF/KM was performed on primitive and functional diagonals with agonist and antagonist patterns of the upper and lower limbs.

\section{Muscle strength}

Isometric muscle strength was measured bilaterally using the grip strength test with the aid of the Instrutherm ${ }^{\circledR}$ digital dynamometer, model DM-90, following the guidelines of the American Society of Hand Therapists (ASHT, 2005-2006). The patient was seated in a chair without armrests, trunk stabilized, back erect, knees flexed at $90^{\circ}$, shoulder slightly adducted, elbow flexed at $90^{\circ}$, forearm and wrist in neutral position. The hand to be tested was fixed to the dynamometer (handle position II), which was held by the examiner. Upon a verbal command, three readings were made on each hand, with a one-minute rest interval between readings. To minimize the effects associated to the initial and final performance, the mean of the three readings was calculated and the patient was instructed not to perform the Valsalva maneuver. The duration of maximum contraction was three seconds. The test was first performed with the right hand without prior warmup, followed by alternating hands between readings. The highest value and mean of the three readings per hand were recorded. The strength evaluation was performed at the pre-invention and post-intervention evaluations (Figueiredo et al., 2007).

\section{Lawton \& Brody activities of daily living scale}

The version of the Lawton \& Brody scale validated, translated, adapted for Portuguese was used for the assessment of performance on activities of daily living. This scale assesses more complex activities, the performance of which is directly related to independent community living. Each item is scored from 0 to 3 points. The total ranges from 0 to 90 points, with higher scores indicative of greater dependence (Lopes \& Virtuoso, 2008). 


\section{Disabilities of Arm, Shoulder and Hand}

The DASH scale is used to assess dysfunctions and limitations of the upper limbs and has been validated, translated and adapted to Portuguese. The functional assessment module has 30 items. Two optional modules for sports/leisure and professional activities each have five items (Orfale et al., 2005).

\section{Short Physical Performance Battery}

The SPPB has been validated, translated and adapted to Portuguese and is used to measure functional performance of the lower limbs. The battery consists of three timed tasks: 1) standing balance; 2) walking at usual pace; 3) standing up from a chair five times. The score ranges from 0 (worst performance) to 12 (best performance) (Nakano, 2007).

\section{Timed Up and Go test}

The TUG test has high reliability for the assessment of the risk of falls. This test is widely used in neurological studies involving stroke survivors. The TUG test is timed and consists of standing up from a chair, walking three meters to a marker on the floor, turning around, walking back to the chair and sitting down with the back against the backrest of the chair. The task is performed as quickly as possible without posing a risk to safety. An execution time of 12 or more seconds is indicative of a greater fall risk (Sasaki, 2015; Lusardi et al., 2017; Ferreira \& Pousa, 2018).

\section{Ethical aspects}

The legal guardian signed a statement of informed consent. This study received approval from the institutional review board of Universidade Federal de Sergipe (certificate number: 3.497.476) and was conducted in accordance with the ethical principles stipulated in Resolution 466/2012 of the Brazilian National Board of Health.

\section{Statistical analysis}

Data analysis was performed with the aid of the Excel 2010 and SPSS version 22 programs. Descriptive statistics were performed, with the calculation of absolute and relative frequencies.

\section{Results}

The analysis of specific activities of daily living using the Lawton \& Brody scale (1969) revealed no improvements in the capacity for independent community living between the pre-intervention and post-intervention evaluations following the administration of PNF/KM. In the analysis of the total Lawton \& Brody scale, no difference was found between the preintervention and post-intervention evaluations regarding the capacity for independent community living (Frame 1). 
Frame 1. Bar graph of Lawton \& Brody activities of daily living scale pré-intervention and post-intervention

\begin{tabular}{|c|c|c|}
\hline \multicolumn{3}{|c|}{ Scale of activities of daily living - ADL } \\
\hline (Lawton \& Brody, 1969) & Pré - Intervention & Post - Intervention \\
\hline \multicolumn{3}{|l|}{ Personal Care ( $R=0$ to 3 ) } \\
\hline a- The feeding & 1 & 1 \\
\hline b- Dress up & 3 & 3 \\
\hline c- Bath & 3 & 3 \\
\hline d- Physiological eliminations & 1 & 1 \\
\hline e- Medication & 3 & 3 \\
\hline f- Interest in personal appearance & 2 & 2 \\
\hline \multicolumn{3}{|l|}{ Household Care $(R=0$ to 3$)$} \\
\hline a- Food preparation, cooking & 3 & 3 \\
\hline b- Table arrangement & 3 & 3 \\
\hline c- Housework & 3 & 3 \\
\hline d- Domestic repairs & 3 & 3 \\
\hline e- Washing clothes & 3 & 3 \\
\hline \multicolumn{3}{|c|}{ Work and Recreation ( $R=0$ to 3 ) } \\
\hline a- Work & 3 & 3 \\
\hline b- Recreation & 0 & 0 \\
\hline c- Organizations & 0 & 0 \\
\hline d- Travel & 1 & 1 \\
\hline \multicolumn{3}{|c|}{ Purchases and Money ( $R=0$ to 3$)$} \\
\hline a- Purchase of food & 2 & 2 \\
\hline b- Use of money & 3 & 3 \\
\hline c- Finance Management & 3 & 3 \\
\hline \multicolumn{3}{|l|}{ Locomotion $(R=0$ to 3$)$} \\
\hline a- Public transport & 3 & 3 \\
\hline b- Driving vehicles & 3 & 3 \\
\hline c- Mobility through the neighborhood & 3 & 3 \\
\hline d- Locomotion outside familiar places & 3 & 3 \\
\hline \multicolumn{3}{|l|}{ Communication ( $R=0$ to 3 ) } \\
\hline a- Use of the telephone & 3 & 3 \\
\hline b- Conversations & 3 & 3 \\
\hline c- Understanding & 3 & 3 \\
\hline d- Reading & 3 & 3 \\
\hline e- Writing & 3 & 3 \\
\hline \multicolumn{3}{|c|}{ Social Relations (spouse) $(R=0$ to 3 ) } \\
\hline a- Family relationships & 3 & 3 \\
\hline b- Family relationships (children) & 3 & 3 \\
\hline c- Friends & 1 & 1 \\
\hline Total scale result & $\mathrm{R}=74$ & $\mathrm{R}=74$ \\
\hline
\end{tabular}

Source: Search results. 
In the analysis of functional changes in the upper limbs evaluated using the DASH scale, the pre-intervention score was $145 / 190$ and the post-intervention score was 140/190, demonstrating functional gains regarding activities that require biomechanical and proprioceptive actions of the shoulders, arms and wrists (Frame 2).

Frame 2. Functional performance of upper limbs using Disabilities of Arm, Shoulder and Hand (DASH).

\begin{tabular}{|c|c|c|}
\hline Disabilities of Arm, Shoulder and Hand (DASH) - (1 to 5) & Pré Intervention & Post Intervention \\
\hline 1- Open a new glass or with the lid too tight & 5 & 5 \\
\hline 2- Write & 5 & 5 \\
\hline 3- Flip a key & 2 & 1 \\
\hline 4- Prepare the meal & 5 & 5 \\
\hline 5- Open a heavy door & 3 & 2 \\
\hline 6- Put something on the shelf above your head & 5 & 4 \\
\hline 7- Doing heavy housework & 5 & 5 \\
\hline 8- Do garden work & 5 & 5 \\
\hline 9- Make the bed & 5 & 5 \\
\hline 10- Carrying a bag or briefcase & 4 & 4 \\
\hline 11- Carrying a heavy object (more than $5 \mathrm{~kg}$ ) & 5 & 5 \\
\hline 12- Changing an overhead light bulb & 5 & 5 \\
\hline 13- Wash or dry hair & 5 & 5 \\
\hline 14- Wash your back & 4 & 4 \\
\hline 15- Wearing a closed blouse & 4 & 3 \\
\hline 16- Using a knife to cut food & 5 & 5 \\
\hline 17- Recreational activities that require little effort (eg, playing cards, knitting) & 4 & 3 \\
\hline $\begin{array}{l}\text { 18- Recreational activities that require force or impact on the arms, shoulders or hands (eg } \\
\text { playing volleyball, hammering). }\end{array}$ & 4 & 3 \\
\hline $\begin{array}{l}\text { 19- Recreational activities in which you move your arm freely (such as fishing, playing } \\
\text { shuttlecock) }\end{array}$ & 2 & 2 \\
\hline 20- Transport yourself from one place to another (go from one place to another). & 4 & 3 \\
\hline 21- Sexual activities. & 5 & 5 \\
\hline $\begin{array}{l}\text { 22- In the past week, at what point did your problem with your arm, shoulder or hand affect } \\
\text { your normal activities with family, friends, neighbors or colleagues? }\end{array}$ & 4 & 2 \\
\hline $\begin{array}{l}\text { 23- During the past week, were your work or normal daily activities limited due to your arm, } \\
\text { shoulder or hand problem? }\end{array}$ & 4 & 3 \\
\hline 24- Pain in the arm, shoulder or hand. & 1 & 1 \\
\hline 25- Pain in the arm, shoulder or hand when you did specific activities & 1 & 1 \\
\hline 26- Skin discomfort (pins in the arm, shoulder or hand. & 1 & 1 \\
\hline 27- . Weakness in the arm, shoulder or hand. & 2 & 2 \\
\hline 28- Difficulty moving arm, shoulder or hand. & 3 & 2 \\
\hline $\begin{array}{l}\text { 29- During the past week, how much difficulty have you had sleeping because of pain in your } \\
\text { arm, shoulder or hand? }\end{array}$ & 1 & 1 \\
\hline $\begin{array}{l}\text { 30- I feel less capable, less confident and less useful because of my arm, shoulder or hand } \\
\text { problem. }\end{array}$ & 3 & 3 \\
\hline
\end{tabular}


31- use of your usual technique to play an instrument or practice sport? 32- play the instrument or practice the sport because of pain in the arm, shoulder or hand? 33- . play your instrument or play the sport as well as you'd like? 34- spend the same amount of time playing your instrument or practicing the sport? 35- spend the same amount of time playing your instrument or practicing the sport? 36- Do your usual work because of pain in your arm, shoulder or hand?

37- do your job as well as you would like?

38- Spend the same amount of time doing your job?

Total scale result

\begin{tabular}{|c|c|}
\hline 5 & 5 \\
\hline 5 & 5 \\
\hline 5 & 5 \\
\hline 5 & 5 \\
\hline 5 & 5 \\
\hline 5 & 5 \\
\hline 5 & 5 \\
\hline 5 & 5 \\
\hline $\mathrm{R}=145$ & $\mathrm{R}=140$ \\
\hline
\end{tabular}

Source: Search results.

The analysis of functional performance using the SPPB revealed important improvements in variables that require stabilization, strength, balance and agility of the lower limbs, as demonstrated by the change in the total score from 4 at the pre-intervention evaluation to 8 at the post-intervention evaluation (frame 3).

Frame 3. Lower limb performance evaluated using Short Physical Performance Battery before and after intervention with $\mathrm{PNF} / \mathrm{KM}$

\begin{tabular}{|c|c|c|}
\hline \multicolumn{3}{|c|}{ Short Physical Performance Battery (SPPB) } \\
\hline & Pré - Intervention & Post - Intervention \\
\hline Standing position with feet together & 1 & 1 \\
\hline Standing position with the foot partially in front & 1 & 1 \\
\hline Standing position with the foot forward & 0 & 2 \\
\hline Walking speed test (4 meters) & 1 & 1 \\
\hline 5 times chair lift test & 1 & 3 \\
\hline Final Test Result & $\mathrm{R}=4$ & $\mathrm{R}=8$ \\
\hline
\end{tabular}

Source: Search results.

In the analysis of the risk of falls using the TUG test, an increase in the execution time of the test was found between the pre-intervention evaluation (28 s) and post-intervention evaluation (19.9 s) (Figure 1). 
Figure 1. Execution velocity of Timed Up and Go test before and after intervention.

\section{Timed up and go test (TUG)}

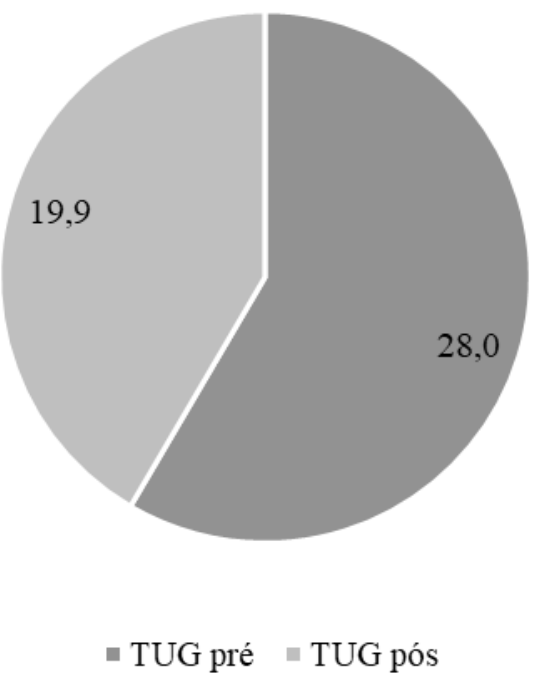

Source: Search results.

The analysis of upper limb muscle strength revealed a gain following the intervention with PNF/KM. Right grip strength increased from 4.7 to $5.8 \mathrm{~N}$ and left grip strength increased from 5.1 to $6.5 \mathrm{~N}$ (Figure 2).

Figure 2. Upper limb strength $(\mathrm{N})$ before and after intervention determined using digital dynamometer (Instrutherm ${ }^{\circ}$, model DM-90).

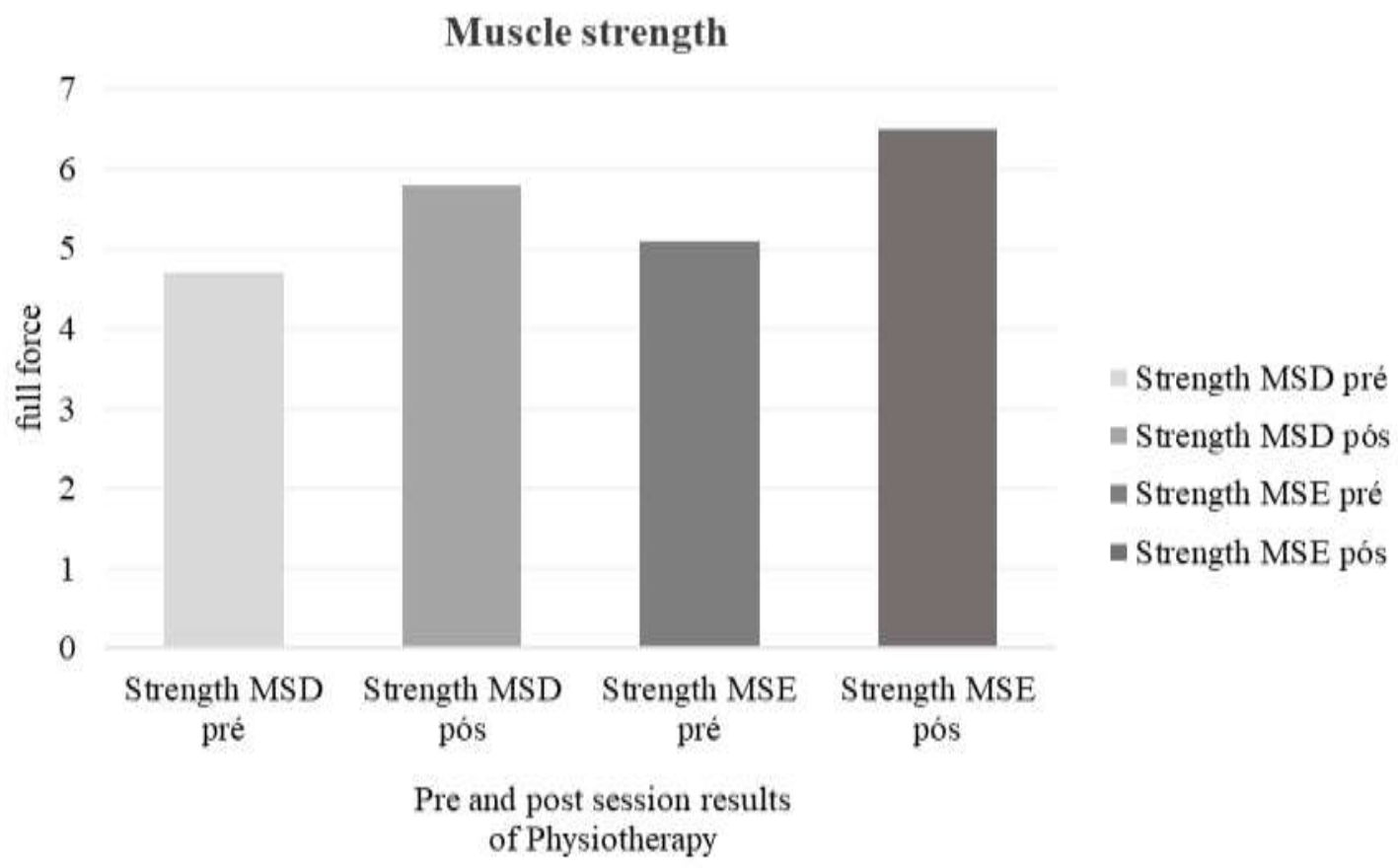

Source: Search results. 


\section{Discussion}

Seckel syndrome is a rare disease that affects motor development if not treated adequately with physiotherapeutic resources that exert a direct effect on the abnormal sensory-motor experience of these patients. As a rare syndrome, studies involving physiotherapeutic approaches that can enhance neurofunctional performance in these patients are rare. Due to this scarcity of studies and the difficulty encountering new cases with an established clinical diagnosis, most medical and dental case reports do not enable comparing results with those from other reliable studies. This scarce but relevant clinical evidence motivated the present study involving the Kabat method of proprioceptive neuromuscular facilitation (PNF/KM) as the physiotherapeutic intervention to investigate its effect on improving motor performance in SCKL.

No significant improvements in performance on activities of daily living were found between the pre-intervention and post-intervention evaluations following treatment with PNF/KM. This finding may be related to the learning difficulty resulting from the syndrome. Mo et al. (2015) report that individuals with this syndrome may present mental retardation due to the small brain size. Another factor that may have contributed to this lack of an improvement was the number of sessions, which may have been insufficient to achieve improvements in activities of daily living. Therefore, further longitudinal studies should be conducted with a larger number of sessions and an increase in the frequency of the intervention sessions (Mo et al., 2015).

The analysis using the Disabilities of Arm, Shoulder and Hand (DASH) scale revealed functional gains in upper limb function, suggesting improvements in activities that require biomechanical and proprioceptive actions of the shoulders, arms and wrists. The DASH score (maximum total: 190 points) reduced from 145 points at the pre-intervention evaluation to 140 points at the post-intervention evaluation, corresponding to a 3.5\% improvement. According to Franchignoni et al. (2010), higher DASH scores denote greater dependence and lower DASH scores denote greater independence with regards to upper limb function. In a study employing sensory-motor stimulation through assisted active exercises [stimulation exercises in "cat" position (on all fours); exercises in "cat" position on balance board and trampoline; training in standing position on foam rubber mat, balance board and trampoline; stimulation to roll over; training of sitting to standing], Ceni (2013) demonstrated the possibility of motor improvement in patients with this syndrome. In the same study, the author cited other stimulation methods for motor development, such as the Bobath method, Cuevas Medek, hydrotherapy and Rolfing. Based on these presuppositions, it is reasonable to assume that $\mathrm{PNF} / \mathrm{KM}$ can also contribute to the maximization of motor functioning in these patients, as demonstrated in the present investigation (Franchignoni et al., 2010; Ceni, 2013).

With regards to motor performance evaluated using the Short Physical Performance Battery (SPPB), significant gains were found in stabilization, strength, balance and agility. The patient went from a total score of 4 points at the pre-intervention evaluation to 8 points at the post-intervention evaluation. An SPPB score close to zero corresponds to the worst performance and a score of 12 points corresponds to the best performance. According to Pavasini et al. (2016), a low score on this test is associated with the loss of mobility, disability, hospitalization and a longer hospital stay in the older population. The present results suggest that the improvement in motor performance was related to the gains in strength and balance achieved through the intervention with PNF/KM (Nakano, 2007; Pavisini et al., 2016).

The execution time on the Timed Up and Go test went from 28 seconds at the pre-intervention evaluation to 19.9 seconds at the post-intervention evaluation, which is an improvement of approximately $40 \%$. According to Lusardi et al., an execution time of 12 or more seconds is indicative of a greater risk of falls. The present results indicate that the intervention with PNF/KM reduced the risk of falls in the patient, as demonstrated by the shorter execution time; however, the patient continued to be a fall risk after the intervention. This may be related to the duration of treatment and frequency of the sessions, which may have been insufficient to resolve problems of balance, acquisition of strength and activation of joint proprioceptors resulting from the syndrome. Another important factor is that SCKL causes biomechanical postural disorders. According to 
Sanglard et al., postural problems can limit the recovery of ambulation and functional independence, which can exert negative impacts on gait, balance and performance on activities of daily living. Nonetheless, the findings suggest that the method was effective at minimizing biomechanical disorders and enhancing the performance of activities of daily living (Sanglard et al., 2004; Lusardi et al., 2017).

In the analysis of grip strength, a $23.4 \%$ increase was found in the right hand - going from $4.7 \mathrm{~N}$ in the preintervention evaluation to $5.8 \mathrm{~N}$ in the post-intervention evaluation - and a $27.4 \%$ increase was found in the left hand - going from 5.1 to $6.5 \mathrm{~N}$, respectively. The difference in gain between the right and left hands may have been due to the fact that the left was the dominant side in the patient, contributing to the greater gain in the left upper limb. According to Kofotolis et al. (2005), proprioceptive stimuli in PNF, such as resistance and stretching stimuli, enable learning with positive repercussions on motor control expressed by improvements in muscle strength and power, the awareness of movement, direction, stability and balance (Kofotolis et al., 2005).

The present study has limitations that should be considered. The lack of studies with a neurofunctional approach to physiotherapeutic treatment for patients with SCKL impeded the comparison of the findings. Moreover, the development of the study was restricted to a case report. This was related to rareness of the disease and the fact that a reliable clinical diagnosis depends on costly DNA, cytogenetic and metabolic tests.

\section{Conclusion}

The Kabat method of proprioceptive neuromuscular facilitation did not lead to improvements in the performance of activities of daily living in a patient with Seckel syndrome, which could be attributed to the discrete mental retardation presented by the patient. However, the method proved effective at improving motor performance involving balance, stabilization, strength and agility of the upper and lower limbs. The present investigation is a pioneering study that presents the results of a therapeutic intervention involving proprioceptive neuromuscular facilitation in a rare syndrome and can serve as the basis for the development of further scientific studies involving this syndrome and interventions with neurofunctional physiotherapy. It is suggested that further studies be carried out with the use and comparison of new therapeutic methods, in order to expand the possibilities in the functional rehabilitation of patients diagnosed with the syndrome.

\section{Acknowledgments}

We thank the Federal University of Sergipe for encouraging the research practices, the physiotherapy department at UFS, the patient and family for their collaboration with the case study, as well as all the authors for their valuable corrections and collaborations in the construction stages of this work.

\section{References}

Akkurt, M. O., Pakay, K., Akkurt, I., Temur, M., \& Korkmazer, E. (2019). Prenatal diagnosis of Seckel syndrome at 21 weeks' gestation and review of the literature. J Matern Fetal Neonatal Med, 32(11), 1905-1908. https://doi.org/10.1080/14767058.2017.1419467.

Ceni, D. C. (2013). Fisioterapia na Síndrome de Seckel: proposta de intervenção através de estimulação sensório-motora (Master's thesis, Universidade Tecnológica Federal do Paraná). http://repositorio.utfpr.edu.br/jspui/handle/1/751.

Cilento, M. B. R., Martins, J. V. P., \& Silva, L. G. (2018). Fisioterapia neurofuncional a pacientes com doenças neurológicas: facilitação neuromuscular proprioceptiva e prática baseada em evidências. In: Associação Brasileira de Fisioterapia Neurofuncional; Garcia CSNB, Facchinetti LD, organizadores. PROFISIO Programa de Atualização em Fisioterapia Neurofuncional: Ciclo 5. Porto Alegre: Artmed Panamericana: p 49-84. (Sistema de Educação a Distância, v.4).

Cruz-Machado, S. S., Cardoso, A. P., \& Silva, S. B. (2007). O uso do princípio de irradiação da facilitação neuromuscular proprioceptiva em programas de reabilitação: uma revisão. São Paulo: Universidade do Vale do Paraíba. http://cronos.univap.br/cd/INIC_2007/trabalhos/saude/inic/INICG00306_01C.pdf. 
Ferreira, A. M., \& Pousa, D. R. (2018). Reabilitação nas fraturas proximais do fêmur. In: Associação Brasileira de Fisioterapia Traumato-Ortopédica; Silva MF, Barbosa RI, organizadores PROFISIO programa de Atualização em Fisioterapia Traumato-Ortopédica: Ciclo 1. Porto Alegre: Artmed Panamericana; p. 67-95. Sistema de Educação Continuada a Distância, v. 2.

Figueiredo, I. M., Sampaio, R. F., Mancini, M. C., Silva, F. C. M., \& Souza, M. A. P. Teste de força de preensão utilizando o dinamômetro Jamar. Acta Fisiátrica. 2007;14(2). Disponível em: https://www.revistas.usp.br/actafisiatrica/article/view/102799.

Franchignoni, F., Giordano, A., Sartorio, F., Vercelli, S., Pascariello, B., \& Ferriero, G. (2010). Suggestions for refinement of the Disabilities of the Arm, Shoulder and Hand Outcome Measure (DASH): a factor analysis and Rasch validation study. Arch Phys Med Rehabil, 91(9), 1370-1377. https://doi.org/10.1016/j.apmr.2010.06.022.

Kofotolis, N., Vrabas, I. S., Vamvakoudis, E., Papanikolaou, A., \& Mandroukas, K. (2005). Proprioceptive neuromuscular facilitation training induced alterations in muscle fibre type and cross-sectional area. Br J Sports Med, 39(3), e11-e11. https://doi.org/10.1136/bjsm.2004.010124.

Lopes dos Santos, R., \& Virtuoso Júnior, J. S. Confiabilidade da versão brasileira da escala de atividades instrumentais da vida diária. Revista Brasileira em Promoção da Saúde 21.4 (2008): 290-296. https://www.redalyc.org/articulo.oa?id=40811508010.

Lusardi, M. M., Fritz, S., Middleton, A., Allison, L., Wingood, M., Phillips, E., \& Chui, K. K. (2017). Determining risk of falls in community dwelling older adults: a systematic review and meta-analysis using posttest probability. J Geriatr Phys Ther, 40(1), 1. https://doi.org/10.1519/JPT.0000000000000099.

Mo, K., Vn, N., \& Sa, U. (2015). Is the novel SCKL3 at 14q23 the predominant Seckel locus? Eur J Hum Genet, 23(1), 140-140. https://doi.org/10.1038/ejhg.2014.258.

Nakano, M. M. (2007). Versão Brasileira da Short Physical Performance Battery - SPPB: Adaptação Cultural e Estudo da Confiabilidade. [dissertação]. Campinas: Faculdade de Educação, Universidade Estadual de Campinas - UNICAMP. http://repositorio.unicamp.br/jspui/handle/REPOSIP/252485.

Orfale, A. G., Araujo, P. M. P. D., Ferraz, M. B., \& Natour, J. (2005). Translation into Brazilian Portuguese, cultural adaptation and evaluation of the reliability of the Disabilities of the Arm, Shoulder and Hand Questionnaire. Braz J Med Biol Res, 38(2), 293-302. https://doi.org/10.1590/S0100879X2005000200018

Orphanet (2020). Prevalência das doenças raras: Dados bibliográficos, Relatórios Orphanet, Coleção Doenças Raras, https://www.orpha.net/consor/cgibin/Education_Home.php?lng=PT.

Pachajoa, H., Saldarriaga, W., \& Isaza, C. (2010). Síndrome de Seckel, dos casos en una familia colombiana. Revista chilena de pediatría, 81(5), 432-436. http://dx.doi.org/10.4067/S0370-41062010000500007.

Pavasini, R., Guralnik, J., Brown, J.C., Di Bari, M., Cesari, M., Landi, F., \& Stenholm, S. (2016). Short physical performance battery and all-cause mortality: systematic review and meta-analysis. BMC medicine, 14(1), 215. https://doi.org/10.1186/s12916-016-0763-7.

Sanglard, R. C. F., Henriques, G. R. P., Ribeiro, Â. D. S. B., Corrêa, A. L., \& Pereira, J. S. (2004). Alterações dos parâmetros da marcha em função das queixas de instabilidade postural e quedas em idosos. Fitness \& Performance Journal, (3), 149-156. https://dialnet.unirioja.es/servlet/articulo?codigo=2954370.

Sasaki, A. C. (2015). Desempenho em dupla tarefa como preditor de quedas em uma coorte de pacientes após acidente vascular cerebral. Salvador: Universidade Federal da Bahia. (Doctoral Thesis). https://repositorio.ufba.br/bitstream/ri/18655/1/Tese_Med_Adriana\%20Campos\%20Sasaki.pdf.

Seckel, H. P. Bird-headed dwarfs. Sptingfield: ccthomas; 1960. P. 111.

Sisodia, R., Raj, R. K. S., \& Goel, V. (2014). Seckel syndrome: a rare case report. Journal of Indian Society of Pedodontics and Preventive Dentistry, 32(2), 160. https://www.jisppd.com/text.asp?2014/32/2/160/130983.

Umphred, D. (2011). Reabilitação neurológica. Elsevier Brasil.

Vascone, C., Di Meglio, F., Di Meglio, L., Turco, L. C. L., Vitale, S. G., Cignini, P., \& Cianci, S. (2014). Antenatal diagnosis of Seckel Syndrome: a rare case report. J Prenat Med, 8(3-4), 70. PMID: 26266004.

Verloes, A., Drunat, S., Gressens, P., \& Passemard, S. (2013). Primary autosomal recessive microcephalies and Seckel syndrome spectrum disorders. In GeneReviews®[Internet]. University of Washington, Seattle. https://pubmed.ncbi.nlm.nih.gov/20301772/.

Ventura, M. M. (2007). O estudo de caso como modalidade de pesquisa. Revista SoCERJ, 20(5), 383-386. 